\title{
Náboženství a modernita v současné sociologii náboženství
}

\author{
Religion and Modernity in the Contemporary Sociology \\ of Religion
}

Roman Vido

\begin{abstract}
The paper deals with the question of the relationship between modernity and religion. Classical secularization theories supposed that with the advance of modernity, traditional religion loses its social influence and significance as well as its hold over the lives of modern individuals. This belief has become known as the "secularization thesis". However, empirical research has not confirmed such a prophecy: religion still represents an important element in the social world. Sociologists of religion have been forced to revise their theoretical notions and concepts and admit that the impact of modernity on religion may be more complex and ambiguous than their predecessors had claimed. The text introduces several authors who are interested in theoretical reflections on the fate of religion in modern society and who share belief in the ability of modernity to produce its own specific forms of religion different from the traditional ones.
\end{abstract}

KEYWORDS religion, modernity and postmodernity, secularization, modernization, multiple modernities, sociology of religion

Diskuse o náboženství a moderních společnostech se po dlouhý čas pohybovaly v mantinelech vymezených sekularizačním paradigmatem, odvíjejícím se od základní teze o neslučitelnosti, resp. problematické slučitelnosti náboženství a modernity (Beckford 1989, Tschannen 1991, Davie 2007). Postupem času ovšem narůstalo množství kritických hlasů, které se tázaly, zdali je tato teze tváří v tvář empirii udržitelná. Následující řádky budou věnovány právě tomuto problému, přičemž budu sledovat argumentační linii, která konstatuje, že univerzálním osudem náboženství v moderní době není pokles jeho významu (natož vymizení), nýbrž transformace, a odmítá tudíž tzv. sekularizační tezi v její klasické podobě (Berger 1967, Wilson 1969). ${ }^{1}$ Tento př́stup bychom mohli s jistým zjednodušením nazvat „durkheimovským“,

Sociální studia. Fakulta sociálních studií Masarykovy univerzity, 3-4/2008. S. 25-49. ISSN 1214-813X. Je nutno připojit důležitou metodologicko-konceptuální poznámku, že musíme rozlišovat mezi sekularizaci jako konceptem, resp. deskriptivním označením určitého procesu (který sám o sobě může být multidimenzionální - viz nap̌r. Shiner 1967, Sommerville 1998, Dobbelaere 2002), sekularizačni tezi jako tvrzením o poklesu společenského významu náboženství v moderních společnostech, sekularizačními teoriemi jako výklady sekularizačního procesu (sekularizačních procesů) a sekularizačním paradigmatem jako obecnou sociologickou perspektivou charakterizující náhled 
poněvadž to byl právě tento francouzský klasik sociologie, kdo konstatoval rozpad tradičních forem náboženství (Durkheim 2004: 145-146) a současně ohlašoval prríchod forem nových, v jeho době však ještě blíže neidentifikovaných (Durkheim 2002: 461). Pozornost bude soustředěna na otázku, jakých podob nabývá náboženství jakožto instituce a religiozita jakožto individuální dimenze náboženství dnes, tj. v éře rozvinuté/pozdní modernity.

Klasické teze sekularizačních teorií přitom nemusejí být nutně zavrženy, poněvadž se mohou ukázat použitelnými pro vysvětlení osudů náboženství v rámci určitého přesně vymezeného časového úseku² a určitého přesně definovaného geografického prostoru (Davie 2007). ${ }^{3}$ Jinak je tomu ovšem s ohledem na současný globalizující se/globalizovaný svět. Ten se totiž podle řady autorů vyznačuje určitými specifiky, která mají významný vliv na aktuální podobu náboženství. ${ }^{4}$ Současný náboženský vývoj je tak v porovnání s minulostí třeba chápat jako daleko více diverzifikovaný a nepředvídatelný a jen sotva uchopitelný v čistě lineárních termínech (Lambert 2004).

Text předložené přehledové stati se odvíjí v několika logicky navazujících krocích. Nejprve si všímám debaty, která se počátkem 90. let rozběhla v sociologii náboženstvís a výrazněji otevřela téma potřeby revize dřívějších představ o vztahu náboženství a modernity. ${ }^{6}$ Klíčové příspěvky v této souvislosti reprezentují práce P. L. Bergera, D. Martina a J.

na osudy náboženství v modernitě. Nepřijetí posledně dvou jmenovaných nevede automaticky k odmítnutí konceptu sekularizace, stejně jako řady postřehů, kterými sociologii obohatily starší či novější sekularizační teorie (samy vnitřně různorodé - blíže viz napřs. Glasner (1977), Dobbelaere (1984) nebo Tschannen (1991)).

2 K pohledu na proces sekularizace $\mathrm{v}$ evropském kontextu $\mathrm{z}$ historického hlediska blíže viz např. Bruce (1992), Rémond (2003), McLeod, Ustorf (2003) nebo McLeod (2007).

3 Nástinu, rozboru ani srovnání nejdůležitějších sekularizačních teorií v této stati nebude poskytnut prostor, nebot’ toto netvoří její jádro. Přehledně se s nimi lze seznámit např́íklad u Lužného (1999) nebo Dobbelaera (2002).

$4 \quad$ Problematika vztahu náboženství a globalizace v současném světě (resp. vztahu mezi procesy globalizace a sekularizace) tvoří jednu z důležitých otázek soudobé sociologie náboženství. V této stati ji ovšem rovněž nebude věnována bližší pozornost. Čtenáře lze v tomto př́ípadě odkázat na některé významné texty zabývající se touto otázkou. V této souvislosti je třeba zmínit především teoretické práce Rolanda Robertsona (Robertson 1985, Robertson, Chirico 1985, Robertson 1989, 1993) a Petera Beyera $(1994,1998,1999,2006)$ a dále empirické studie věnující pozornost vztahu mezi globalizací a sekularizací (např. Halman, Petterson 2003 či Dobbelaere 2004). Krátký přehled některých důležitých teorií nabízí Lužný (1999).

5 Zde by se slušelo dodat „anglosaské“ sociologii náboženství. Avšak vzhledem k tomu, že tato (ještě i dnes) do značné míry udává tón sociologii náboženství jako takové (podobně jako v případě sociologie obecně), ponechávám danou formulaci bez onoho přívlastku.

6 V této souvislosti je nutno připomenout tradici americké sociologie náboženství, která se vždy nacházela $\mathrm{v}$ paradigmaticky alternativní pozici vůči v Evropě dominantnímu paradigmatu sekularizačnímu a z jejíhož lůna byly pravidelně (již od 60. let - např. A. Greeley či R. N. Bellah) vznášeny kritiky namířené vůči „evropským“ sekularizačním teoriím. Tento trend nabyl na síle v 80. letech s vydáním důležitých prací R. Starka a W. S. Bainbridge $(1985,1987)$ opírajících se o z ekonomie vycházející teorii racionální volby a s konstituováním se tzv. nového paradigmatu (blíže viz Warner 1993 nebo Young 1997). Stavění evropské a americké tradice sociologie náboženství proti sobě je opodstatněné, ovšem možné jen za cenu jistého zjednodušení a paušalizace. K historickému pře- 
Casanovy. Poté bliže představuji teorii modernizace Ronalda Ingleharta, jejímž těžištěm je reflexe hodnotové proměny (západních) společností, a koncepci multiple modernities Shmuela N. Eisenstadta, kterou lze chápat jakožto doplnění ${ }^{7}$ a současně i kritiku ${ }^{8}$ Inglehartova pohledu na modernizaci a vztah mezi různými rovinami společnosti (ekonomická, politická, kulturní). ${ }^{9}$ $\mathrm{V}$ další části předestírám několik vybraných př́spěvků z diskuse o podobách náboženství $\mathrm{v}$ (pozdní) modernitě, která proběhla $\mathrm{v} 90$. letech 20 . století. Zaměřuji se cíleně na autory a autorky, kteří (až na výjimku v osobě J. A. Beckforda) nepocházejí z anglosaského kontextu a jejichž koncepce nejsou v českém sociologickém prostředí tak známé jako kupř́kladu práce Grace Davie, Paula Heelase či Danièle Hervieu-Léger, ačkoliv rovněž přinášejí řadu zajímavých postřehů. Spojující článek těchto prríspěvkủ tvoří reflexe procesu sekularizace a proměn náboženských forem $\mathrm{v}$ kontextu pozdní modernity $\mathrm{v}$ západních společnostech. $\mathrm{V}$ závěru se pak - inspirován G. Davie - zamýšlím nad dalším směřováním sociologického zkoumání náboženství v současném světě počátku 21. století.

\section{Náboženství a modernita - neslučitelné koncepty?}

Specifickou pozici mezi sociology náboženství, kteří zpochybňují základní východiska sekularizační teorie, zaujímá Peter L. Berger - a to z jednoduchého důvodu: tento autor sám patřil mezi jedny z nejvýznamnějších reprezentantů sekularizačního paradigmatu. Jeho kniha The Sacred Canopy. Elements of a Sociological Theory of Religion (1967) bezpochyby náleží do zlatého fondu teoretických prací o sekularizaci i sociologie náboženství vůbec. Přesto lze u něj od 70. let zaznamenat ústup z dřivějších pozic, který následně vyvrcholil v 90 . letech, kdy Berger přichází s tezí o desekularizaci světa a veřejným uznáním svého omylu coby dřívějšího zastánce sekularizační teze (Berger 1999). „Předpoklad, že žijeme v sekularizovaném světě, je mylný. Dnešní svět je až na pár výjimek [...] stejně zaníceně náboženský, jako vždy býval, a některých místech ještě více" (Berger 1999: 2). ${ }^{10}$

hledu vývoje moderní sociologie náboženství viz Cipriani (2000), v češtině např. částečně Nešpor (2004).

7 Zatímco Inglehartovu perspektivu můžeme vnímat jako diachronní (sleduje rozdíly v rámci vývoje v čase), zaujímá Eisenstadt primárně perspektivu synchronní (srovnává rozdíly v rámci prostoru).

8 Inglehartovo pojetí modernizace bylo původně zakotveno v tzv. konvergenčním nahlížení na modernizační proces, ve kterém modernizace sleduje jeden jediný uniformní scénár. Později své stanovisko zčásti revidoval (Inglehart, Baker 2000, Inglehart, Norris 2004).

9 Výběr těchto autorů je veden skutečností, že právě jim přisuzuje vysokou míru relevance britská socioložka Grace Davie (2007), jejíž úvahy tvoří obecný teoreticko-analytický rámec této stati (viz dále v textu).

10 V této souvislosti upozorňuje Inglehart (1997) na určitý zdánlivý paradox, který v sobě slučuje klasickou sekularizační tezi i Bergerův ,anti-sekularizační“ pohled. Podle Ingleharta platí, že takřka všechny společnosti vyspělého západního světa se v průběhu posledních 50 let sekularizují a přitom ve světě jako celku stoupá počet lidí s tradičními náboženskými názory (roste jejich proporce). Klíčem k vysvětlení tohoto trendu je klesající fertilita charakteristická pro ony sekularizující se společnosti v porovnání s její vysokou mírou ve společnostech méně modernizovaných. 
Vztah mezi náboženstvím a modernitou není tak jednoznačný, jak se teoretikové sekularizace (včetně Bergera samotného) v 60. letech domnívali. Současný svět ukazuje, že postupující modernizace nemusí nutně vést k oslabení náboženství a sekularizace na úrovni societální automaticky neimplikuje sekularizaci na rovině individuální. Navíc - sekularizační trend může vyvolat mocné anti-sekularizační procesy. Jeden z prríkladů falzifikace sekularizační teorie podle Bergera představuje skutečnost, že nejlépe se na podmínky modernizace adaptovaly ty náboženské skupiny, které nejméně ustoupily požadavkům sekularizovaného světa. Sekularizační teorie přitom hovořily o dilematu adaptace ,pokles vs. interní sekularizace“, které dávalo šanci jen těm podobám náboženství, které vyjdou vstř́ic „odkouzlenému“ světu.

Podporu pro své přesvědčení o neadekvátnosti sekularizačních předpokladů nachází Berger hned v několika soudobých fenoménech: růstu konzervativních a evangelikálních církví v USA, oslabování liberálních církví, trvalém zájmu o náboženství v dalších západních zemích (,believing without belonging“) a vitalitě náboženství v rozmanitých koutech dnešního světa (od Latinské Ameriky až po jihovýchodní Asii). Současnost je podle něj stavem „masivní religiozity“. Existují zde jen dvě výjimky. První z nich tvoří západní Evropa (i zde však Berger preferuje spíše pojmenování „posun v institucionálním zakotvení náboženství“ než „sekularizace“), druhou mezinárodní „subkultura“, sestávající z lidí s vyšším vzděláním západního typu (zejména humanitního a společenskovědního), která je sice početně malá, nicméně velmi vlivná coby kulturní elita. ${ }^{11}$

Proti této Bergerově „konverzi“ se staví Steve Bruce (2001), který se domnívá, že Bergerova sekularizační teorie zůstává v zásadě nadále v platnosti a její odvolávání není na místě. Argumenty, které Berger uvádí proti teoriím sekularizace, nejsou podle Bruce dostatečně přesvědčivé. Např́klad současná náboženská situace v zemích tzv. třetího světa nemůže být základem pro kritiku tezí sekularizačních teorií. Podobně ani „,indicie“ z USA či jiných západních zemí nejsou dostatečně průkazné (Bruce 2001: 89-91). Citujme Bruce:

Nerozumím tomu, proč se Berger domnívá, že náboženská vitalita v zemích třetího světa má nějakou souvislost s jeho prací o sekularizaci. [...] (S)ekularizační teze netvrdí, že plynutí času podkopává náboženství. Jedná se spíše o soubor spolu souvisejících tvrzení ohledně dopadu určitých společenských změn v určitých podmínkách. Je zjevné, že prohlášení, že pluralismus klade na stát požadavek rostoucí neutrality ve věcech víry, odkazuje pouze k demokraciím (či alespoň k politickým systémům ovlivněným principem rovnosti) a velmi omezenému počtu autokracií, jež mají dobrý důvod vyhnout se náboženskému a etnickému konfliktu. V ostatních př́ípadech se lze setkat s daleko obvyklejší reakcí na diverzitu, a to se zabitím či vypuzením těch, co se odlišují. [...] Vytvoření klimatu, v němž mohou alternativy mírumilovně koexistovat a soutěžit za rovných podmínek, představuje pouze jednu z možností. A ta je typickou pouze pro moderní liberální demokracie. Berger sám psal o podmínkách, za nichž lze očekávat, že jeden aspekt modernizace oslabí náboženství. Je pak obtížné pochopit, proč o třicet let později prezentuje jakožto důkaz proti svým původním argumentům osud náboženství ve zcela odlišných podmínkách. (Bruce 2001: 92)

11 Právě tato skupina lidí je podle Bergera hlavním nositelem progresivních, osvícenských hodnot a přesvědčení. 
Základními nedostatky Bergerova odvolání dřívějších názorů na sekularizaci jsou tedy nepřesvědčivost empirických dat (USA, západní Evropa) a problematické chápání statusu sekularizační perspektivy. Sekularizační teorie podle Bruce nepředstavují univerzální výkladová schémata, nýbrž pouhá „historická vysvětlení specifických změn v náboženském klimatu určitých společnosti““ (Bruce 2001: 95). Aplikovat tento výklad i na jiné společnosti lze pouze do té míry, do jaké se zde vyskytují procesy, jež byly identifikovány jakožto klíčové faktory (př́íčiny) v původních, výchozích podmínkách, tvořících základnu pro sekularizační „proroctvi“".

S podobnou skepsí se lze setkat i u dalšího z význačných teoretiků sekularizace Davida Martina, který je znám již svými dřívějšími kritickými výhradami ke konceptu sekularizace (Martin 1969), stejně jako úsilím o kontextualizaci někdy až př́liš zjednodušených představ o postupu sekularizačního procesu (Martin 1978). Ve své stati z počátku 90. let (Martin 1991) se znovu zamýšlí nad klíčovým „axiomem“ teorií sekularizace o nekompatibilitě modernity a náboženství a dochází $\mathrm{k}$ závěru, že sekularizace by měla být pokládána za víceméně nahodilý, nikoliv nutný a nevyhnutelný trend, typický pro vývoj v po-osvícenské Evropě. Je to právě Evropa, pro níž byl sekularizační model navržen a k níž nejspíše také přináleží. Pokud se týče ostatních částí světa, tak ty, ač Evropou mnohdy silně ovlivněny, jí nejsou nijak determinovány, a proto se jejich společenský a náboženský vývoj nemusí nutně ř́́dit stejnou logikou, jaká ŕídila běh událostí na „starém kontinentě““.12

A do třetice je to José Casanova (1994), kdo zpochybňuje sekularizační tezi o klesající vitalitě náboženství v moderním světě. Skrze rozbor konceptu sekularizace ukazuje, že ani privatizace náboženství, ani jeho „pokles“ nejsou nezbytnými důsledky vyplývajícími z procesu funkcionální diferenciace jakožto definiční charakteristiky modernizace. Na základě přehledu empirických údajů dochází k závěru, že z globální perspektivy lze konstatovat, že od konce 2. světové války zažívá většina náboženských tradic ve velké části světa bud' určitý růst, nebo si svou životaschopnost alespoň udržuje. Existují zde však tři důležité výjimky, z nich je na prvním místě třeba jmenovat náboženskou situaci ve většině západní Evropy (plus některých jejích dř́ivějších koloniálních územích). ${ }^{13}$ Západní Evropa ${ }^{14}$ je ve sledovaném období svědkem postupujícího a trvalého poklesu tradičního náboženství. Právě tato skutečnost podle Casanovy stála v základu většiny sekularizačních teorií. Při snaze o vysvětlení tohoto trendu se ovšem tradiční odkaz k modernizaci (jakožto komplexu procesů zahrnujícím institucionální diferenciaci, industrializaci a urbanizaci) ukazuje být nedostatečným, čehož důkazem je konfrontace s Japonskem či Spojenými státy, které reprezentují podobně vyspělé a moderní společnosti. Klíč k objasnění „evropské výjimečnosti““ je podle Casanovy třeba hledat v těch

12 Souhrnnou reflexi nad svým dlouholetým zaobíráním se problematikou sekularizace a postavení náboženství (zejména křest’anství) v moderním světě předložil Martin ve své zatím poslední knize On Secularization. Towards a Revised General Theory, která představuje soubor přednášek, které byly proneseny a zčásti i publikovány (až na jednu výjimku) v letech 1999-2004 (Martin 2005).

13 Další výjimky tvoří tzv. původní (primal) náboženství a náboženství v komunistických zemích (blíže viz Casanova 1994: 27).

14 Pod pojmem ,západní Evropa“ chápe Casanova veškeré území v Evropě, které bylo součástí západního křest’anství - tj. římskokatolickou a protestantskou Evropu. 
nezávislých nositelích sekularizace, které jsou specifickými pro evropský prostor. Casanova je spatřju v podobě vztahů mezi státem a církví a v povaze evropského osvícenství (Casanova 1994: 11-39).

\section{Od modernizace $\mathrm{k}$ postmodernizaci}

Důležitý př́íspěvek do diskuse o podobách a důsledcích procesu modernizace vnesl se svou teorií postmodernizace ${ }^{15}$ (postmaterialismu) Ronald Inglehart (1977, 1990, 1997), který se ve svých úvahách opírá o rozsáhlý projekt empirických šetření nazvaný World Values Survey. ${ }^{16}$ Inglehart vychází z tradičního chápání procesu modernizace (Marx, Weber, Durkheim) jakožto procesu, který zvyšuje ekonomické a politické možnosti společnosti prostřednictvím industrializace, která tvoří jeho jádro. ${ }^{17}$ Základním cílem na celospolečenské rovině je ekonomický růst. Od něj se pak odvíjí i individuální motivace členů moderních společností (Inglehart 1997). Ústřední proces industrializace s sebou nese celý komplex přidružených socio-kulturních změn (urbanizace, masové vzdělávání, profesní specializace, byrokratizace, aplikace vědy a technologie, rozvoj komunikačních médií).

Inglehart ovšem upozorňuje, že éra modernizace není finálním stádiem společensko-historického vývoje. ${ }^{18}$ Modernizační proces totiž v sobě do současné doby obsahuje dva různé přechody, dvě zásadní socio-ekonomické změny: přerod pre-industriální éry v éru industriální ekonomiky (,klasická“ modernizace) a následně transformaci industriální ekonomiky v ekonomiku postindustriální (postmodernizace). ${ }^{19}$ „Postmodernizace reprezentuje pozdější stádium vývoje, které je spojeno s velmi odlišnými přesvědčeními (beliefs), než je to, které charakterizovalo modernizaci. Tato přesvědčení nejsou pouhými důsledky ekonomických či sociálních změn, nýbrž formují socioekonomické podmínky a souběžně jsou jimi i sama formována“ (Inglehart 1997: 8).

Důležitý bod Inglehartovy teorie spočívá v tvrzení, že obě socio-ekonomické změny současně provází posuny ve sféře hodnotových orientací. Vedle toho tvoří druhou klíčovou oblast vyspělých industriálních společností, v níž se odehrávají významné změny, oblast instituci-

Inglehart rozhodně není jediným a ani prvním autorem, který s podobnými úvahami přišel. Za všechny jmenujme např́ílad známou práci D. Bella The Coming of Post-Industrial Society (1973). Specifikem Inglehartovy koncepce je koncentrace na problematiku hodnot a hodnotových orientací, tedy sféru důležitou s ohledem na náboženství.

16 Inglehartovu koncepci české odborné veřejnosti představil již na počátku 90. let 20. století Rabušic (1990).

17 Samotný koncept modernizace se (podobně jako koncept sekularizace) stal předmětem četných diskusí, v němž byl zpochybněn jeho status a jeho použitelnost (Casanova 1994: 239). Tato problematika je ovšem natolik komplexní a rozsáhlá, že jí v této práci nebude věnován větší prostor. Blíže viz napřr. Keller (2007).

18 Podobně i Dobbelaere píše, že modernita není „pevným stavem“, nýbrž „vyvíjející se situací, jež je zřetelně vyjádřena v konceptech post- či pozdní modernity“ (Dobbelaere 2004: 139).

19 První přechod reprezentuje přesun od ekonomiky založené na zemědělství k ekonomice založené na průmyslu, zatímco druhý přechod představuje posun směrem k hospodářství opírajícímu se o terciární (služby, obchod), prrípadně kvartérní sektor (informace). 
onální struktury. Zatímco pro popis prvního z přechodů lze použít nástroje tradičních teorií modernizace (včetně jejich důležité součásti v podobě sekularizační teorie), je tomu v př́padě posunu do éry post-industrialismu jinak. Klasické teorie modernizace (a tedy i sekularizace) mají svou hodnotu, jsou-li aplikovány na první fázi modernizace, nicméně selhávají při snaze zachytit adekvátně proměny vyplývající z nástupu vyspělé (advanced) modernity, kdy nárůst $\mathrm{v}$ oblasti hmotného blahobytu dosáhl bodu, kdy se již nadále nepřetavuje do paralelního nárůstu ve vnímání kvality života.

Pokud jde o sféru hodnot, hovoří Inglehart v této souvislosti o vynoření se nové, postmaterialistické hodnotové orientace, respektive o posunu od materialistických $\mathrm{k}$ postmaterialistickým hodnotám v populacích vyspělých moderních společností. ${ }^{20}$ Jádro postmaterialistických hodnot tvoří důraz na duševní pohodu, kvalitu života a seberealizaci (nikoliv na materiální blahobyt a fyzické bezpečí). V rovině proměn institucionální struktury pak představuje nejvýraznější trend oslabení hierarchicky uspořádaných byrokratických organizací, které se přiblížily limitům vlastní funkcionální efektivnosti a široké aplikovatelnosti. Současně platí, že tyto organizace se stávají stále méně príijatelnými pro „postmoderni““ veřejnost, charakterizovanou výše zmíněným hodnotovým posunem.

Při odpovědi na otázku, co stojí za postmoderní proměnou hodnot a posunem směrem k postmaterialistickému pohledu na svět, předkládá Inglehart svou koncepci mezigenerační hodnotové změny, jež je založena na dvou základních hypotézách. První z nich - hypotéza nedostatku - ř́ká, že jedincovy hodnotové priority odrážejí socioekonomickou situaci, do níž je zasazen. Člověk přisuzuje nejvyšší subjektivní důležitost tomu, čeho se mu nedostává. Druhá hypotéza - hypotéza socializace - konstatuje, že vztah mezi hodnotovými prioritami a socioekonomickými podmínkami není záležitostí bezprostředního přizpůsobení se. Naopak - existuje zde určitá časová „mezera“, jelikož hodnotová orientace člověka odráží zásadním způsobem situaci, která charakterizovala formativní léta jeho vývoje. Aplikují-li se tyto obecné teze na problematiku vývoje moderních industriálních a postindustriálních společností, ukáže se, že v základu postmaterialistického hodnotového posunu leží fundamentální rozdíl mezi situací, kdy jedinec vyrůstá s vědomím nejistoty ohledně fyzického př̌žití ve světě, a situací, kdy je toto přežití vnímáno jako samozřejmost.

Ekonomické zázraky a sociální státy, které se objevily po 2. světové válce, přivodily nové stádium v dějinách a rozhodujícím způsobem tak položily základ pro vzestup postmoderních hodnot. Fundamentální změny ve formativních zkušenostech daly vzniknout specifickému hodnotovému systému u narůstajícího segmentu těch, kteří dospívali ve vyspělých industriálních společnostech během let po 2. světové válce. Po válce narozené kohorty v těchto společnostech vyrůstaly v podmínkách, které byly podstatně odlišné od těch, které formovaly předchozí generace. [...] Poprvé v dějinách vyrůstala velká část obyvatelstva s pocitem, že přežití lze brát za samozřejmost. To vedlo k procesu mezigenerační hodnotové změny, která postupně transformuje politiku a kulturní normy vyspělých industriálních společností. (Inglehart 1997: 32)

20 Termín postmodernizace pak označuje daný komplex socio-ekonomických změn, který je doprovázen zmíněným hodnotovým posunem. 
Kombinace prosperity (ekonomický růst) a bezpečí (sociální stát) tak přispěla ke snižujícímu se pocitu ,zranitelnosti“ vůči nepříznivým silám prrírody a osudu mezi obyvateli nejvyspělejších zemí, který vyústil v hodnotový posun od materialismu k postmaterialismu. ${ }^{21}$ $\mathrm{S}$ jeho př́ichodem dochází k oslabení důrazu na ekonomický růst, ale i vědecký a technický rozvoj, a k akcentaci subjektivního pocitu „kvalitního života“. Tento trend se projevuje v rozmanitých oblastech lidského života (vztah k autoritám, náboženství, politika, genderové role či sexuální normy). ${ }^{22}$

Co se týče náboženství, je třeba jeho postavení v rámci postmodernizačního procesu vnímat v širším kontextu měnících se postojů k autoritám. Modernizace přinesla v tomto ohledu přechod od náboženských k racionálně-byrokratickým autoritám. Postmodernizace v této linii pokračuje a v jistém smyslu ji dovádí do krajních důsledků - odmítnuta je jak náboženská, tak byrokratická autorita. Vývoj se posouvá k obecnému oslabení role autority (všech forem) a ke zdůraznění úlohy a autonomie jedince (pluralismus, demokratizace). Rezervovanost k dřívějším autoritám se odráží i na postojích k tradičním normám. Dủležitou roli zde hrají dva faktory: klesající potřeba absolutních pravidel v důsledku rostoucího pocitu bezpečí a snižující se funkčnost některých norem související s poklesem významu některých společenských institucí (napřr. rodina či náboženství). Preferovány jsou nyní normy zaměřené na snahu o individuální sebenaplnění.

Navzdory mnohým změnám, které s sebou v porovnání s modernizací přináší postmodernizace, zde existují i mnohé kontinuity. K nejvýznamnějším z nich patří kromě pokračující a sílící individualizace i sekularizace. Ačkoliv dochází k poklesu prestiže vědeckého pohledu na svět, jehož rozmach byl zejména ve weberovsky laděných sekularizačních teoriích jedním z hlavních faktorů sekularizace (kognitivní rovina), sekularizační proces působí dále. Důvodem je podle Ingleharta skutečnost, že rostoucí pocit ekonomického bezpečí v hospodářsky vyspělých zemích snižuje potřebu ujištění o spáse, kterou tradičně poskytovaly náboženské organizace. ${ }^{23}$ Důležitou roli zde hraje i výše zmíněný postmoderní „odpor“ vůči autoritám.

21 Inglehart zdůrazňuje, že vztah mezi ekonomickou rozvinutostí společnosti a převahou postmaterialistických hodnot není přímočarý, poněvadž hodnoty, které jedinci vyznávají, neodrážejí ekonomickou vyspělost země samu o sobě, ale spíše subjektivni pocit bezpečí. Proto je třeba brát v úvahu nejen hospodářské bohatství dané země, ale i kulturní kontext a rozvinutost institucí sociálního státu.

22 Postmaterialismus ovšem neznamená anti-materialismus. Jedná se spíše o označení souboru hodnotových cílů, které jsou zdůrazňovány poté, co lidé dosáhli určité úrovně materiální zabezpečenosti, a protože dosáhli této úrovně. Proto si lze představit hodnotový zvrat v př́ípadě, kdy by došlo k narušení stavu bezpečí. Jde o posun v prioritách.

23 V tomto ohledu se Inglehartova koncepce podobá tzv. kompenzačnímu vysvětlení (compensation thesis) religiozity, které předkládá např. Ch. Glock (Glock, Stark 1965). Podle něj je nárůst religiozity a vzestup náboženských hnutí spjat s lidmi pocit’ovanou deprivací, kdy náboženství poskytuje kompenzaci za zakoušené strádání. Podle Dobbelaera však empirická data tuto tezi obecně nepotvrzují. Lidé ve vyspělých industriálních zemích, kteří pocit’ují deprivaci, nehledají kompenzaci v náboženských zdrojích. Hlavním důvodem je kolaps plauzibility tradičních náboženství (Dobbelaere 2002: 139). Je ovšem třeba zdůraznit, že Inglehartova koncepce je daleko komplexnější a propracovanější a její těžiště leži jinde. Podobnost s Glockovou teorií je tedy jen omezená. Obě 
Bylo by ovšem mylné ztotožňovat postmodernizaci (jakož i modernizaci) s ústupem náboženství. Oba procesy lze spíše vnímat jako procesy oslabování tradičních forem náboženství. Inglehart se domnívá, že duchovní zájmy jsou součástí „lidského údělu“ (human condition), na čemž nic nemění ani eroze některých jejich historických, institucionalizovaných „materializací“. „Ačkoliv postmodernismus provází pokračující oslabování tradičních náboženských věr, pojí se s ním rostoucí zájem o smysl a cíl života“ (Inglehart 1997: 80). Postmoderní společnosti proto mohou být svědkem existence nových podob religiozity či spirituality a tedy jakéhosi nového ,zakouzlení“, které je ovšem výrazně ovlivněno postmaterialistickými hodnotami (např. hnutí New Age).

\section{Evropa jako výjimka}

Problematikou modernizace se v návaznosti na Bergerovy, Martinovy a Casanovovy úvahy poukazující na specifičnost či výjimečnost postavení (západní) Evropy vzhledem k procesu sekularizace zabývá i britská socioložka Grace Davie (1999, 2001, 2002, 2003, 2007). Ve své práci s výmluvným názvem Europe: The Exceptional Case (2002) se detailně věnuje popisu evropské ,,výjimky“ a snaze nalézt kořeny tohoto stavu, přičemž využívá komparativního postupu. $\mathrm{V}$ jeho rámci srovnává náboženskou situaci v západní Evropě se situací v jiných částech světa (Spojené státy, Latinská Amerika, Afrika, Dálný východ). ${ }^{24}$ Předběžný závěr z této analýzy pak vyznívá jednoznačně: neplatí teze, že náboženství není slučitelné s modernitou. Opak je pravdou.

Při hledání odpovědi na otázku po kořenech specifické sekularizovanosti evropského kontinentu nastoluje Davie otázku konceptuálních nástrojů pro adekvátní sociologické zachycení této ,výjimky“،

Máme-li prokázat, že model náboženství v Evropě je vskutku výjimečným př́padem, musíme se ptát, vůči čemu je výjimečný? Existuje někde jinde nějaká norma? A pokud ano, kde, a v čem tato norma spočívá? Lze to formulovat i jiným způsobem: Je možné, že Evropa tvoří výjimku v termínech své komparativní sekularity, avšak zbytek světa (nebo jednodušeji: jiné části křest'anského světa) nevykazuje pouze jeden, ale mnoho př́kladů náboženské vitality, které se - a to je klíčový bod - liší od sebe navzájem stejně jako od západní Evropy. (Davie 2002: 137)

Následné otázky tedy zní: „Od čeho přesně se Evropa liší (je to jedna věc nebo mnoho?) a lze tyto odlišnosti konceptualizovat teoreticky stejně jako empiricky (tj. v př́padových studiích)?“ (Davie 2002: 150). Při hledání vhodných analytických nástrojů se Davie obrací ke „geografické“ metafoře, když užívá termínu konceptuální mapa, který má vyjadřovat analogii k mapě zeměpisné. Její jádro vysvětluje takto:

koncepce nicméně spojuje poukaz na významnou úlohu pocitu (zejména ekonomického) bezpečí člověka pro vazbu k tradičním formám náboženství.

24 Davie se soustřed'uje na osudy křest’anského náboženství ve světě, a proto z ne-evropských regionů věnuje pozornost těm oblastem, v nichž je výrazným způsobem přítomno právě křest’anství (např. Brazílie, subsaharská část Afriky, Jižní Korea či Filipíny). 
mapu Alp nelze jednoduše přenést na Skalnaté Hory či Andy (a naopak) bez vážných následků. Důsledek, který je zde třeba zdůraznit, představuje fakt, že užití nesprávné konceptuálni mapy je právě tak zavádějící (a stejně nebezpečné) jako užití nesprávné zeměpisné mapy, a to ve vícero ohledech. Nejenže nám takové mapy ukazují nevhodné cesty, ale stejně tak mohou odvést výzkumníkovu mysl od cest, které si vyžadují pozornost. (Davie 2000: 151)

Proto podle Davie není správné začínat analýzu od předpokladu výjimečnosti, ${ }^{25}$ založeného na představě jakési normy, resp. něčeho, co je typické, ale spíše se snažit vytvořit nespecifickou, obecnou „mapu hor“, kterou lze následně použít a prrizpůsobit pro jednotlivé konkrétní případy.

V rámci tohoto svého úsilí se Davie obrací ke klasickému konceptu modernizace, který tvoří nedílnou součást všech sekularizačních teorií, kdy jsou modernizace a sekularizace vnímány jako vzájemně propojené procesy. Nad tento vztah je položen otazník: „Je ústup náboženství, či přesněji řečeno určitých forem náboženství nutným znakem moderní krajiny (tj. vnitřním rysem modernizačního procesu) nebo pouze něčím nahodilým (tj. vnějším v tom smyslu, že se může vyskytovat v některých př́ipadech, ale v jiných ne)?“ (Davie 2002: 152). Jako vhodné teoretické zdroje pro řešení tohoto problému se Davie ukazují být př́stupy dvou autorů, jejichž úvahy se odvíjejí dosti odlišnými směry.

První z nich reprezentuje výše nastíněná Inglehartova teorie postmodernizace. Druhý z možných přístupů pak ztělesňuje Shmuel N. Eisenstadt (2000) se svou myšlenkou mnohočetných modernit (multiple modernities). ${ }^{26}$ Její základ tvoří zpochybnění dvou tradičních západních představ: předpokladu, že modernizace, již postupují různé společnosti, působí konvergentně; a chápání Evropy jakožto „vůdkyně“ modernizačního procesu. V Eisenstadtově pohledu lze modernímu světu porozumět nejlépe tehdy, pokud na něj budeme nahlížet jako na „př́iběh kontinuální konstituce a rekonstituce multiplicity kulturních programů“ (Eisenstadt 2000: 2). Tyto rekonstituce jsou výsledkem trvalých aktivit jedinců i skupin, které se podílejí na vytváření a znovuvytváření kulturních a institucionálních formací, a to v různých ekonomických, kulturních a sociálních kontextech. Jádro modernity lze chápat spíše než jako nějaký soubor pevných charakteristik jakožto postoj, který byl ve své původní podobě nesen především přesvědčením, že budoucnost je v rukou člověka a jeho cílevědomého jednání. Konkrétní podoby realizace ,projektu modernity“ se následně odlišují podle různých kontextů, v nichž se odehrávaly. Diverzita podob modernity není známkou jejího neúspěchu, nýbrž jejím stvrzením - je to součást modernity samotné.

Důležitý faktor, který se podle Eisenstadta v současné době podepisuje na měnící se povaze modernity, představuje proces globalizace, který výrazným způsobem ovlivňuje podobu a fungování moderních národních států. Za této situace se na společenské scéně vyno-

25 Davie (1999) rovněž poukazuje na jistý paradox ve vývoji sociologických analýz náboženství v moderních společnostech, který lze demonstrovat na posunu od představy americké výjimečnosti (American exceptionalism), typické pro klasické teorie sekularizace z 60. let 20. století, k predstavě evropské výjimečnosti (European exceptionalism), charakteristické pro mnohé současné koncepce (byt' v jistém smyslu předjímané americkými teoretiky racionální volby).

26 S koncepcí mnohočetných modernit při zkoumání problematiky náboženství pracují i další současní autoři (např. Hefner 1998, Spohn 2003 či Katzenstein 2006). 
řují noví sociální aktéři ve formě celé řady sociálních hnutí, jejichž zájem se soustřed'uje na existující problémy moderního světa (např. feministická či environmentalistická hnutí). Místo zde nachází i náboženství a náboženská hnutí v rozmanitých podobách, které odrážejí rozmanitost podob modernity. Jak upozorn̆uje Davie s odkazem na N. Göle ${ }^{27}$, patř́i mezi základní charakteristiky modernity schopnost sebe-korekce. A právě zde se podle Davie otevírá pole pro náboženství.

Hlavní př́nos, který podle Davie přináší koncepce Eisenstadta, spočívá ve dvou bodech: 1) je třeba si uvědomit, že evropská verze modernity je pouze jednou z možných verzí mezi jinými a podobně jako ony prochází procesem neustálé rekonstrukce; 2) konceptuální nástroje, které vycházejí z evropské zkušenosti, nemusejí být postačující pro analýzy v jiných prostředích a kontextech, a proto je nutno hledat nové teoretické prístupy, abychom byli schopni plně pochopit povahu náboženství v moderním světě, at’ už v Evropě či mimo ni.

\section{Náboženské produkty modernity}

Jedním z autorů, který rovněž zpochybňuje tradiční vnímání vztahu mezi modernitou a náboženstvím a současně přichází s konstruktivním příspěvkem do diskuse o moderních formách náboženství, je nizozemský religionista Staf Hellemans (1998). Jádro jeho koncepce tvoří konstatování, že vztah náboženství a modernity není vztahem opozice, nýbrž provázanosti. ${ }^{28}$ Hellemans upozorňuje, že klasické29 teorie sekularizace vypracované v podstatě jednou generací sociologů náboženství v průběhu 60 . a 70. let 20. století odrážely reálnou zkušenost těchto autorů s náboženskou situací v západním světě, přičemž se opíraly o práce klasiků sociologické/sociální teorie, které se rovněž odvíjely od percepce modernity jakožto sekularizaci podléhající historické epochy. Tato kombinace zajistila sekularizačním teoriím silnou présvědčivost a de facto paradigmatický status. Na rozdíl od mnohých teoretických koncepcí 18. a 19. století však nejsou teze sekularizačních teorií vyjádřením cíleného politického programu (sekularismus), ale mají představovat reflexi reality. Sekularizace je vnímána jako strukturní rys modernity, výsledek objektivních procesů v moderní společnosti (modernizace). Jako její konečný důsledek není předpokládán zánik náboženství, nýbrž jeho marginalizace..$^{30}$

Pokud jde o otázku po možnostech a způsobech přežití náboženství v podmínkách modernity, lze $\mathrm{v}$ rámci klasických sekularizačních teorií nalézt tento pohled: náboženství se bud' uzpůsobí moderní době (interní sekularizace, „odkouzlení), anebo ztratí na svém společenském významu (externí sekularizace). Teoretikové sekularizace nepopírají, že

27 A jistě lze v této souvislosti připomenout i myšlenky dalších teoretiků modernity - např. A. Giddense, U. Becka či J. Habermase.

28 Hellemans poznamenává, že přesvědčení o nutném procesu poklesu náboženství v moderním světě bylo mezi sociálními vědci natolik rozšířené, že s prvními teoriemi, které hovoří o specificky moderních podobách náboženství (tj. náboženstvích, jež jsou specifickými produkty modernity), se lze setkat až v 60. letech 20. století u autorů, jako jsou Luckmann (1967) či Bellah (1964, [1967] 1990).

29 Používám-li v textu v souvislosti se sekularizačními teoriemi přívlastku „klasickéc, mám tím na mysli právě teorie rozpracované $\mathrm{v} 60 .-70$. letech.

Bliže ke kontextu vzniku sekularizačních teorií viz Tschannen (1994). 
i v soudobých společnostech existuje prostor pro náboženské jednání a zkušenosti. Vzhledem k jejich konceptualizaci modernity jakožto sekularizující a sekularizované však nejsou vyhlídky - zejména tradičního, organizovaného - náboženství příliš povzbudivé. Hellemans smír̆livě konstatuje:

Sekularizační teoretikové generace Bergera, Dobbelaera, Luckmanna, Wilsona aj. učinili, co učinit museli, aby důkladně reflektovali velké náboženské změny a vývoj v jejich době. Náboženské klima se ovšem mezitím změnilo. [...] Oživající přitažlivost náboženství obecně a rozmach ortodoxních a fundamentalistických náboženských hnutí zvláště stojí v protikladu vůči explanačnímu úsilí sekularizační perspektivy. (Hellemans 1998: 71)

Tento rozpor mezi teorií a empirickou realitou se pak odráží v četné kritice sekularizačního paradigmatu. Objevují se alternativní výklady, které se často snaží obrátit sekularizační perspektivu ,na hlavu“".

Hellemans tento přistup neakceptuje, nýbrž navrhuje vycházet z „neutrálních pozic“ (tj. ne z anti-sekularizačních), přičemž klíčovým inspiračním zdrojem je mu německý sociolog Niklas Luhmann. „Perspektiva, kterou chci obhajovat, nevychází z opozice mezi náboženstvím a modernitou, jež leží v základu sekularizačních teorií, ale bere si za svůj startovní bod opačnou myšlenku - blízkou provázanost náboženství a modernity“ (Hellemans 1998: 72). V rámci tohoto prŕístupu není náboženství považováno za cizorodý prvek uprostřed modernity, ale za její integrální součást. Hellemans na něj pohlíží jako na dynamický systém, který vstupuje do interakcí se svým průběžně se měnícím prostředím a hledá způsoby, jak se na něj nejlépe adaptovat. Tuto adaptaci ovšem nelze chápat jako tak či onak „násilné“ přizpůsobení se modernitě ve stylu, v jakém teoretikové sekularizace popisují ono dilema adaptace (interní sekularizace) vs. úpadek (externí sekularizace). Modernita je érou kontinuálního vytváření nových, moderních forem náboženství a náboženské transformace forem tradičních. Hellemans proto modernitu charakterizuje do češtiny obtížně přeložitelným anglickým termínem religiogeneous. ${ }^{31}$

Pokud jde o proces sekularizace, ten Hellemans nevylučuje, protože způsoby adaptace, jež náboženství v modernitě hledá, se - z pohledu náboženství samotného - nemusejí vždy ukázat jako úspěšné. Sekularizace se v této nové perspektivě mění z apriori očekávaného výsledku působení modernizace na náboženství, odvozeného z obecné teorie založené na ideji nekompatibility náboženství a modernity, na pouhou možnost (byt' mnohdy reálnou). Nadále proto pro sociologii zůstává důležitou otázkou. Sekularizační teorie si již nicméně nemohou nárokovat „paradigmatický status“, který jim po dlouhou dobu v rámci sociologického zkoumání náboženství přináležel.

Základní posun své perspektivy směrem od sekularizačního paradigmatu pak Hellemans shrnuje do tří bodů: 1) sekularizace není nadále vnímána jako nutný vedlejší produkt modernizace; 2) tradiční náboženství uprostřed modernity nejsou pokládána za zastaralé relikty premoderní doby a liberalizace v oblasti teologie, morálky a rituálů není považována za jediný

31 Jak můžeme vidět např. u T. Luckmanna (1967), není představa specificky moderní náboženské ,produkce“ zcela novou a objevnou. Za jejího významného předchůdce lze pokládat již E. Durkheima s jeho předpokladem príichodu „nových bohů““. 
možný zpo̊sob, jak se mohou s modernitou vyrovnat; 3) problém sekularizace se stává empirickou otázkou, nikoliv paradigmatickým výchozím bodem.

\section{Tři prahy sekularizace}

Jiné uchopení problematiky, které Hellemansovy úvahy vhodně doplňuje, nabízí francouzský sociolog Yves Lambert (1999), který navrhl obecný model vztahů mezi náboženstvím a modernitou. Modernita je v jeho rámci chápána v jaspersovském smyslu jakožto nová „osová doba“, v níž dochází k přetvoření symbolického pole (Bourdieu) a objevení se nových náboženských konfigurací. ${ }^{32}$ Znamená tak výzvu dosavadním náboženským tradicím a současně i potenciální zdroj náboženské inovace. K základním rysům modernity řadí těchto sedm fenoménů: moderní věda a technologie, touha po svobodě, vynoření se masy jakožto dějinného aktéra, globalizace, primát rozumu, rozvoj kapitalismu a funkcionální diferenciace. ${ }^{33}$ Samotné kořeny modernity jsou lokalizovány do 15.-16. století, přičemž její následný rozvoj je periodizován do čtyř fází: počátek (zrod moderní vědy, kapitalismu a buržoazie), rozmach (osvícenství, éra revolucí, zrod moderní vědecké metody a myšlení, rozvoj industrialismu), vrchol (triumf kapitalismu a industrialismu, vznik národních států, rozmach socialismu, nacionalismu a kolonialismu a následně pak dekolonialismus, globalizace, triumf demokracie a sociálního státu) a současná fáze (od 60 . let). ${ }^{34}$

Lambert ve své analýze sleduje efekty výše zmíněných sedmi rysů modernity na náboženství a přitom rozlišuje jejich čtyři typy: pokles (ústup), adaptaci či reinterpretaci, konzervaci a inovaci. Náboženská situace každého konkrétního státu je pak důsledkem způsobu, jakým výše uvedené faktory (rysy) historicky fungovaly. ${ }^{35}$ Obecně však lze tvrdit, že není na místě hovořit o nutném spojení mezi modernitou a mizením náboženství (či náboženského) - vyjma jeho tradičních forem a podoby náboženského monopolu. Moderní situaci náboženství lze spíše popsat v termínech náboženského přetváření v rámci obecného symbolického přetváření. „Současná fáze se zdá být fází rozvoje [...], kde nové formy doplňují, redefinují či nahrazují formy dřívější, ačkoliv ne bez určitého odporu (fundamentalismus) či významné míry ne-víry v některých zemích“ (Lambert 1999: 324).

32 Jaspers rozlišuje čtyři klíčové historické etapy: neolitická éra, éra nejstarších civilizací, éra velkých světových říší a moderní éra, přičemž jakožto „osovou dobu“ on a následně další autoři vnímají historické období okolo 6.-5. století př. n. 1., které bylo svědkem zrodu univerzalismu, filozofie, tzv. světových náboženství a rané vědy. Lambert se však domnívá, že výrazu „osová doba“ je možno použít na všechna čtyři uvedená období.

33 První čtyři položky pocházejí od Jasperse, zbývající pak doplnil Lambert.

34 Pro toto období se v sociologické literatuře užívá různých označení, která v sobě nesou jeho různé konceptualizace: např. postindustrialismus, postfordismus, informační společnost, společnost vědění apod. Lambert odmítá označení „postmodernita“ a přiklání se ke Giddensově myšlence radikalizované a univerzalizované reflexivní modernity.

35 Diverzitu účinků modernity na náboženství v závislosti na politickém a socio-kulturním kontextu jednotlivých zemí analyzoval již dříve v rámci svého obecného výkladu procesu sekularizace David Martin (1978). 
Jaké místo zaujímá v tomto kontextu sekularizace? Lambert chápe sekularizaci ve smyslu, v jakém ji vymezil Berger (1967), tedy jako „proces, jímž jsou sektory společnosti a kultury oddělovány od nadvlády náboženských institucí a symbolư“. Bergerovo odlišení náboženských institucí a náboženských symboli̊ pak konceptualizuje do podoby dvou prahů sekularizace. ${ }^{36}$ První práh se váže na autonomizaci ve vztahu k náboženským institucím či strukturám autority (institucionální sekularizace), druhý práh souvisí s opuštěním náboženství (symbolická sekularizace). Překročení prvního prahu s sebou nese ztrátu monopolu náboženských institucí a autorit, avšak nikoliv nutně i pokles religiozity. Často uváděnou charakteristiku nitrosvětskosti (this-worldliness) nepokládá Lambert za rys sekularizace, poněvadž z hlediska dějin náboženství tvoří mimosvětsky (other-worldly) orientovaná religiozita spiše výjimku než pravidlo. Rozkvět na „tento svět“ orientované religiozity v éře modernity proto chápe jako ukazatel adaptace, nikoliv sekularizace. ${ }^{37}$

Pokud jde tedy o sekularizaci, konstatuje Lambert, že vezmeme-li v úvahu jím identifikované čtyři typy účinků modernity na náboženství, jde o sekularizaci pouze v př́ípadě náboženského poklesu. Adaptace (reinterpretace) a inovace přispívají k sekularizaci pouze do té míry, v níž obnášejí oproštění se od konzervativní náboženské autority. Konzervace pak znamená př́ímo anti-sekularizační trend, nebot' vede k posílení náboženské autority i religiozity. Přitom platí, že „racionalizace, individualizace a funkcionální diferenciace samy o sobě neimplikují sekularizaci, avšak mohou vést k překročení prahů. Je jisté, že přispívají k překročení prvního prahu tím, že umožňují více autonomie. To ovšem nutně neznamená, že nahrávají i překročení toho druhého, poněvadž samy mohou být zdroji náboženské adaptace, reakce a invence“ (Lambert 1999: 325).

Analýza empirických dat ${ }^{38}$ ze západních zemí ukazuje, že s př́chodem modernity byl první práh ( $\mathrm{tj}$. autonomizace vzhledem $\mathrm{k}$ náboženským institucím) $\mathrm{z}$ velké části překročen, projevem čehož je rozsáhlá institucionální sekularizace, a to na všech třech úrovních: makroúrovni (státy), mezoúrovni (společenské instituce) i mikroúrovni (jedinci). Co se týče druhého prahu, lze říct, že byl překročen pouze $\mathrm{v}$ omezené míre. Výjimku tvoří bývalé komunistické státy a určité společenské sektory (věda, ekonomika) a věkové kategorie (mladí) v některých zemích. Na závěr svého rozboru klade Lambert otázku, zdali se nyní nenacházíme uprostřed vývoje směřuícího ke třetímu prahu, který definuje jakožto pluralistickou sekularizaci a popisuje jako situaci, kdy má náboženství stejnou nadvládu nad společností a životem lidí jako jakákoliv jiná ideologie či hnutí, avšak může sehrávat svou úlohu i mimo svou specifickou náboženskou funkci, a tak mít vliv i vně úzkého okruhu věřících - třeba jako etický či kulturni zdroj. ${ }^{39}$

36 Zde se nechal inspirovat analýzou procesu laicizace francouzského sociologa J. Bauberota.

37 Důležité je v této souvislosti zmínit, jak si Lambert vymezuje náboženství. Za náboženskou Lambert pokládá ,jakoukoliv víru či praxi, která odkazuje k nad-empirické realitě, tj. realitě, která radikálně překračuje objektivní hranice př́rody a člověka, pokud zde existuje symbolický vztah mezi člověkem a touto realitou" (Lambert 1999: 304).

38 Lambert provedl sekundární analýzu dat získaných z projektů WVS (World Values Survey) a ISSP (International Social Survey Programme).

39 Připuštěna je i možnost fungování coby politický zdroj, ovšem za podmínky, že budou respektovány hodnoty individuální autonomie a demokratického pluralismu (Lambert 1998). 


\section{Náboženství jako kulturní zdroj}

Myšlenka, že náboženství může v kontextu vyspělé modernity fungovat spíše než jako sociální instituce jako kulturní zdroj, má své kořeny v sociologické koncepci N. Luhmanna (1977), jíž se následně (mimo Lamberta) nechala inspirovat celá řada současných autorů zabývajících se problematikou náboženství (Beckford 1989, Beyer 1994, Hellemans 1998, Voyé 1999).

Významnou je v tomto ohledu práce Jamese Beckforda Religion and Advanced Industrial Society (1989). Beckford pečlivě analyzuje př́ispěvky, které se objevily na poli sociologie náboženství od dob sociologických klasiků až po konec 20. století. Současně si všímá i proměny $\mathrm{v}$ postavení této sociologické disciplíny $\mathrm{v}$ rámci sociologie jako celku. Jedna $\mathrm{z}$ jeho základních tezí zní: dosavadní sociologický př́stup k problematice náboženství se úzce váže na ideje přechodu od pre-industriální $\mathrm{k}$ industriální společnosti. ${ }^{40}$ Podle Beckforda dosavadní koncepce přinesly mnoho důležitých vhledů a postřehů, avšak vzhledem ke skutečnosti, že náboženství představuje fenomén, který prochází vývojem, je nutno tyto koncepce a ideje aktualizovat, př́padně nahradit novými. Tím základním důvodem je ,jednoduchý fakt, že nyní již nežijeme $\mathrm{v}$ industriálních společnostech toho typu, jaký popisovala zakládající generace západních sociologü“ (Beckford 1989: 169). ${ }^{41}$

Beckford konstatuje, že co se týče snahy či ochoty se odtrhnout od svazujícího kontextu industriální společnosti, jde o poměrně nedávnou záležitost. Až v poslední době se objevují nové perspektivy a čerstvé podněty, které poukazují na novou (resp. přetrvávající) společenskou významnost náboženství. Důležitý indikátor tvoří v této souvislosti kontroverznost, která se mnohdy pojí s působením náboženských skupin v současné společnosti. Podle tradiční sekularizační teorie by se dalo spíše očekávat, že existence náboženství nebude provázena žádným výraznějším ohlasem (Beckford 1999).

Klíčovou charakteristikou soudobého náboženství je podle Beckforda skutečnost, že se do značné míry autonomizovalo. Nadále již není tak striktně (pokud vůbec) vázáno na tradiční společenství a různé jiné tzv. přirozené kolektivity. Užívání náboženské symboliky tudíž není zakotveno $\mathrm{v}$ tradičních společenských celcích, $\mathrm{k}$ jejichž prospěchu by mělo přispívat (viz Durkheim). Náboženské symboly se emancipovaly od svých dř́vějších „vlastníkư“ a staly relativně volným a veřejně přistupným kulturním zdrojem, který může být obdařen různými významy a užíván různými společenskými skupinami k rozmanitým účelům (např. politické, environmentální). Náboženství je dnes vymaněno z tradičního kontextu náboženských organizací, resp. státního institucionalizovaného náboženství. Může být sice nadále nositelem konzervativních idejí národní, kulturní či etnické integrity, ale zrovna tak může působit jakožto

40 Beckford přitom rozlišuje tři široké proudy v rámci sociologického zkoumání náboženství. První vychází z předpokladu, že náboženství funguje v prvé řadě jakožto garant sociální integrace (nap̌r. Durkheim). Druhý si všímá primárně schopnosti náboženství poskytnout ideje řádu a smyslu (např. Weber). Třetí př́stup se pak zaměřuje na ideologické účinky náboženství (napřx. Marx). Všechny tři perspektivy mají své stoupence i v rámci sociologie náboženství 2. poloviny 20. století, kteří se snaží korigovat nedostatky klasických koncepcí. Podle Beckforda ovšem ne zcela dostatečně.

41 Beckford ovšem mezi oběma typy společností nedělá ostrou dělící čáru a připouští, že kromě důležitých změn zde zůstává i celá řada kontinuit. 
nástroj změny či výzvy. Obecně jej lze charakterizovat vyšší mírou flexibility a nepředvídatelnosti. „Poválečná transformace toho druhu industriální společnosti, jakou předvídali sociologové na počátku 20. století, měla tendenci nabourat komunální, rodinné a organizační základy náboženství. Nicméně náboženské formy cítění, víry a jednání přežily jako relativně autonomní zdroje“ (Beckford 1989: 171). Svou analýzu uzavírá Beckford tvrzením, že „[d]eregulace náboženství je jednou ze skrytých ironií sekularizace. Pomáhá učinit náboženství sociologicky problematickým způsobem, který je takřka nepředstavitelný v pojmech sociologických klasiků“ (Beckford 1989: 172).

Nových rolí, které na sebe může brát náboženství v kontextu pokročilé modernity, si všímá i belgická socioložka Liliane Voyé (1999) upozorňující na skutečnost, že tradiční náboženství (v tomto případě konkrétně rímskokatolická církev) sice přichází o svou dřívější autoritu na societální rovině i na rovině subsystémů a zaznamenává ztráty i na úrovni individuální religiozity, avšak nachází nové kanály, skrze něž se dokáže ve společnosti uplatnit. Voyé zde hovoří o modifikaci způsobů, jimiž se sekularizace manifestuje, a současně upozorňuje i na jistý de-diferenciační trend (mezi oblastí politiky a práva na straně jedné a oblastí náboženství na straně druhé). Je třeba ovšem dodat, že tento přetrvávající vliv náboženství je často „,vykoupen“ oslabením jeho specificky náboženských funkcí a podmíněn transformací náboženského diskurzu.

Voyé podobně jako Beckford upozorňuje, že narozdíl od doby, kdy spatřily světlo světa klasické teorie sekularizace (60.-70. léta), se dnes již Evropa nenachází „v srdci triumfující modernity“, nýbrž v etapě ,vyspělé modernity“ (advanced modernity). ${ }^{42} \mathrm{~A}$ to má své důsledky pro oblast náboženství. Ty nicméně nemusejí být v rozporu se sekularizační teorií, nebot' náboženství nezažívá oživení skrze návrat $\mathrm{k}$ pre-modernímu stavu. To je nemožné $\mathrm{v}$ tom smyslu, v jakém definoval sekularizaci jakožto nevratný proces Bruce (2002). Náboženství, pokud si chce uchovat svůj společenský význam, musí hledat nové prostředky, nová pole působnosti. S odkazem na N. Luhmanna naznačuje Voyé, že náboženství se takto „nabízi“ jako zdroj pro jiné subsystémy společnosti, aby demonstrovalo schopnost řešit problémy, které vyvstaly v jiných sférách, avšak nejsou zde řešitelné (např. politická sféra). Na societální rovině se náboženství může uplatnit jakožto nositel obecného etického diskurzu ${ }^{43}$, na individuální rovině pak ve formě lidové religiozity (poskytnutí teritoriální identity), která je ovšem do jisté míry mimo kontrolu a regulaci institucionálních autorit.

\section{Dvě tváře náboženství v ultra-modernitě}

Až doposud jsem se věnoval obecnějším úvahám ohledně vztahu mezi náboženstvím a modernitou, přičemž se moje pozornost soustředila primárně na téma sekularizace. $V$ této souvislosti lze říct, že převládající názor mezi sociology analyzujícími náboženskou situaci v západních společnostech na konci 20. století tvořilo (a tvoří i na počátku 21. století) pře-

42 Za hlavní charakteristiky vyspělé modernity pokládá Voyé relativní skepticismus vůči vědě, ztrátu reputace národního státu (ve prospěch menších či naopak větších celků) a změny v pojetí práva od substancialistického k situačnímu.

43 Právě sem lokalizuje možnost moderního veřejného náboženství Casanova (1994). 
svědčení, že teorie sekularizace jsou v současné době již nedostačujícím nástrojem, který si nicméně nezaslouží být zcela zavrhnut, nebot' některé z jejich základních tezí zůstávají platné (např. Inglehart 1997, Tschannen 1998, Willaime 1998, Davie 2007). Zdá se být totiž neoddiskutovatelným faktem, že moc tradičních náboženských institucí a jejich vliv na jedince i společnost jako celek zaznamenaly v průběhu 20. století (alespoň v západním světě) výrazný pokles. Náboženství již nadále neztělesňuje jednotný, společnost integrující systém významů. Je proto na místě hovořit o sekularizaci na societální úrovni (Dobbelaere 2002). Na druhou stranu jsme ovšem v současné fázi modernity svědky nové společensko-náboženské situace, která představuje výzvu tradičním sekularizačním koncepcím, které nejsou povětšinou schopny adekvátně zachytit nové podoby náboženského života (Riis 1993).

$\mathrm{V}$ poslední části tohoto textu bych se rád věnoval teoretické analýze, která v obecnější rovině nastiňuje, jaké formy náboženství charakterizují současnou fázi modernity v prostředí vyspělých západních společností. Pochopit zdejší současné náboženské trendy nám umožní francouzský sociolog náboženství Jean-Paul Willaime (1998, 2006), vycházející ve svých úvahách z konceptu ultra-modernity. Tímto se přiřazuje k autorům, jako jsou A. Giddens, U. Beck či A. Touraine, kteří odmítají teze o „konci modernity“ a nástupu postmodernity a současnou fázi vývoje západních společností nahlížejí optikou „,radikalizované“, „triumfujíci““ či „dovršené“ modernity. ${ }^{44}$ „Zakoušíme-li dnes konec vítězné modernity, není to proto, že by byla vyčerpaná. Naopak - je to proto, že byla úspěšná“ (Willaime 1998: 262). Willaimeova koncepce je pro současnou sociologii náboženství inspirativní v tom, že se snaží vyslyšet volání po propojení stále dosti izolované subdisciplíny sociologie náboženství s aktuálními teoretickými př́ispěvky obecné (mainstreamové) sociologie a jejími analýzami modernity (Beckford 2003, Davie 2007). ${ }^{45}$ Willaime je totiž správně přesvědčen, že při dnešním sociologickém studiu náboženství a jeho proměn musíme věnovat náležitě důkladnou pozornost rozborům transformací modernity samotné (Willaime 2006: 77-78).

Ultra-modernita představuje radikalizaci modernity, a to zejména s ohledem na její dva základní konstitutivní elementy - reflexivitu a individualizaci. Ultra-modernita je hyperkritická a desakralizující. Tato její tendence se nevztahuje pouze na objekty „klasické“ modernity v podobě tradičních společenských institucí (mezi nimi i náboženství), ale i na modernitu samotnou, čímž přivozuje stav „demystifikace modernity“. Ultra-modernitu charakterizuje zvýšená míra nejistoty, kdy se ohniskem kritického přezkoumání stávají nejen dřívější tradice, ale rovněž moderní politické ideologie, moderní věda, ideál změny a pokroku či hodnoty typu ekonomického růstu a hmotného blahobytu. Produktem ultra-modernity je kulturní laicita (laïcité culturelle), tj. „situace, kdy jedinci zbavují všechny modly jejich posvátné aury a praktikují systematickou kritiku“"(Willaime 1998: 263).

Jaké důsledky mají podmínky ultra-modernity pro pozici náboženství ve společnosti? Jak píše Willaime, ve fázi „,dobývající“ (conquering) modernity, která byla orientována proti tradicím a společensko-kulturnímu statusu quo, bylo tradiční institucionalizované nábožen-

44 K tématu blíže viz Beckford (1996), který tematizuje rozdíl mezi koncepty postmodernity, high modernity a new modernity ve vztahu k sociologickému studiu náboženství.

45 S podobnou snahou z nedávné doby se lze setkat např́klad v textech Campbella (2006), Dawsona (2006) nebo Besecke (2007). 
ství vnímáno jako překážka na cestě ke změně a pokroku, a proto měl být jeho vliv na společnost i jedince výrazně omezen. O modernitě lze v tomto ohledu hovořit jako o sekularizující síle. Situace v „dovršené“ modernitě (tedy ultra-modernitě) se ovšem zcela mění. Potřeba vymanění se z područí náboženství již není přítomna, nebot' vše již bylo „desakralizováno“ dř́ve - at' již na úrovni společnosti (de-institucionalizace, sekularizace), tak jedince (autonomizace, individualizace). Tradiční náboženství, zbavené svých dřívějších pozic a rolí, sice v marginalizované formě přežívá, avšak současně se objevuje i ve svých nových, „hypermoderních“ podobách, které podle Willaimeho „zabraňují ultra-modernitě v tom, aby se rozpadla do sebedestruktivní kritiky“ (Willaime 1998: 264).

Ultra-moderní náboženství nachází svůj výraz ve dvou - na sobě do značné míry nezávislých - formách. K uchopení první z nich si Willaime vypůjčuje Castelssův koncept společnosti sítí (Castells 1996). ${ }^{46}$ Náboženství prošlo během moderní éry procesy de-institucionalizace a individualizace na straně jedné (plodem jsou tzv. náboženství a là carte) a de-kulturalizace ${ }^{47}$ na straně druhé, následkem čehož charakterizuje současné náboženství daleko nižší míra sociální a kulturní strukturovanosti. „Náboženská identita jedinců se stává více a více nejistou a pohyblivou. Žijeme v době synkretismů, mísení tradic: symbolické hranice se staly velmi prostupnými a jedinci jsou vystavováni všemožným druhům nabídek“ (Willaime 1998: 266). Ultra-modernita vytváří reálný ,trh se spásou“. Důležitým aspektem tohoto stavu je nahrazení dřívější vertikální regulace skrze instituce horizontální regulací skrze sítě. V rámci této nové konstelace již jedinci nepřináleží k jedné instituci, jejíž předepsané role, normy a hodnoty přjímají, nýbrž se příležitostně připojují k uskupením založeným na bázi sítí, a to podle svých vlastních preferencí. V této souvislosti se lze setkat s hlasy hovořícími o „krizi přináležení“, která - jak upozorňuje Willaime - není záležitostí pouze náboženské sféry. ${ }^{48}$ Náboženská společenství sítí jsou založená na funkcionálním vztahu jedince k danému společenství a na individualizaci smyslu. Náboženský jedinec není pevně vázán se svými spoluvěrci v rámci nějaké instituce, na níž by byl pro realizaci svých náboženských či duchovních potřeb závislý. Sdružování probíhá na dobrovolném základě. Tato praxe nevyznačuje pouze tzv. nová náboženská hnutí (napřr. New Age), ale proniká i do tradičních náboženských společenství. Je výrazem adaptace náboženství na ultra-moderní realitu de-institucionalizace (podobně též Davie 2007). ${ }^{49}$

Tato forma náboženského života ovšem nevyčerpává možnosti, jež ultra-modernita náboženství nabízí. Přes výrazný proces de-institucionalizace zde totiž přetrvávají i tradiční

46 Práce M. Castellse představují další z inspiračních zdrojů některých současných sociologů náboženství. Kromě J. P. Willaimeho s ním pracuje např. i D. Lyon (2002).

47 Termín de-kulturalizace označuje situaci, kdy se náboženské (v Evropě tedy převážně křest'anské) symboly, narace a náboženský jazyk obecně stávají více hermetickými a hưře pochopitelnými. Tento fakt je dán klesajícím náboženským věděním (a vzděláním) i narušením vztahu mezi slovy a jejich významy v rovině jazyka (např. „Bůh“).

48 O fenoménu „víry bez přináležení“ (believing without belonging) píše obšírněji G. Davie, která na tento jev rovněž nahlíží v širších společenských souvislostech.

49 Tento trend tvoři jádro sociologických diskusí o posunu od náboženství ke spiritualitě, kterému ovšem v tomto textu nebude věnována pozornost. Jako základní zdroj zde čtenářům může posloužit Heelas, Woodhead (2005). 
náboženské instituce, které si nadále do určité míry drží svou historickou a kulturní váhu a sehrávají jistou regulativní úlohu. Náboženství v podmínkách ultra-modernity nelze redukovat na individuální religiozitu. Ačkoliv již tradiční náboženské instituce nemají onen společenský vliv, jež měly dř́ve, přesto nacházejí své pole působnosti ve veřejné a institucionální sfére, a to zvláště na poli sociální etiky. (Této skutečnosti jsme se již dotkli při nastínění konceptu náboženství jakožto kulturního zdroje.) Jinou rovinou, která nabízí možnosti pro působení tradičních podob náboženství, je tzv. lidová religiozita, často obsahující silný teritoriální aspekt (vazba na region, národ apod.). Willaime připomíná i místo, jež v současnosti náboženství zaujímá v kontextu Evropy, kde se manifestuje v podobě náboženských dimenzí kulturního dědictví evropských společností a skrze udržování národní i celoevropské paměti (HervieuLéger 2000, Davie 2000). I v rámci ultra-modernity lze identifikovat role, jež náboženské instituce hrají při symbolickém udržování sociálního pouta. ${ }^{50}$

Ultra-moderní religiozitu tak lze charakterizovat jakožto rozpolcenou mezi logikou sítí, jež funguje na rovině individuálních aktérů, a logikou teritoria, kterou lze nalézt na rovině institucionálního systému:

Vskutku to je tak, jako by ve společensko-náboženské situaci ultra-modernity koexistovaly dvě podoby Boha, aniž by se tyto nutně setkávaly: na rovině individuální religiozity blízký Bůh, pozorný vůči osobnímu životu každého z nás; na societální rovině Bůh vzdálený, který do každodenního života lidí nezasahuje. Zkrátka jakýsi druh polarizace božského obrazu, který koresponduje v náboženské oblasti s oddělením aktéra a systému. (Willaime 1998: 273)

\section{Výzva pro sociologii náboženství}

Předložený text, který sledoval vybrané př́íspěvky ze sociologické diskuse o vztahu modernity a náboženství, bych rád uzavřel kratší úvahou nad směrem, jímž by se do budoucna měla - tváŕí v tváŕ aktuálním náboženských trendům $\mathrm{v}$ dnešním globalizovaném světě - ubírat sociologie náboženství. Je totiž zřejmé, že proměna jejího náhledu na vztah mezi náboženstvím a modernitou se významným způsobem promítá do analýz a interpretací současných náboženských jevů a trendů.

Při hledání odpovědi na tuto otázku se ukazuje být obzvláště podnětnou nejnovější práce G. Davie (2007), která problém budoucí agendy sociologie náboženství explicitně promýšlí. ${ }^{51}$ Vychází přitom z kritiky sekularizačního paradigmatu, které po dlouhou dobu opanovávalo pole sociologického zkoumání náboženství, ačkoliv realita jeho výchozímu předpokladu o nekompatibilitě náboženství a modernity (tzv. sekularizační teze) neodpovídala. V dnešní situaci je zřetelné, že sekularizační perspektiva již není adekvátním nástrojem pro porozu-

50 Willaime v této souvislosti klade otázku, zdali se tradičně zdůrazňovaný proces individualizace nedotýká více náboženských norem než hodnot, následkem čehož pak lidé přijímají náboženské hodnoty (napřs. solidarita či věrnost), které jsou jim připomínány náboženskými institucemi, avšak to, zdali a jestli budou i realizovány, již zůstává na nich samotných.

51 V českém prostředí patří k průkopnickým pracím v oblasti sociologie náboženství, které se snaží reflektovat aktuální trendy a výzvy, publikace Z. Nešpora a D. Lužného Sociologie náboženství (2007). 
mění místu a roli náboženství ve společnosti, a proto je nutno interpretační rámec sociologie náboženství re-konstruovat. V rámci této rekonstrukce je nutno reflektovat evoluci disciplíny a rozpoznat implikace jejích povýtce evropských počátků pro formování sociologického myšlení o náboženství a tam, kde je to nutné, se od nich oprostit. Přitom ovšem není třeba zavrhovat sekularizační teorie zcela.

Davie chce v souladu se svým přesvědčením o pluralitě podob modernit - a tedy i podob vztahů mezi modernitou a náboženstvím - sledovat právě onu rozmanitost forem, jichž může „transcendentno“ v (pozdně) moderních společnostech nabývat. Některé tyto formy byly v předložené stati zmíněny. Taktéž Davie konstatuje, že v současné fázi modernity můžeme být svědky různých variant vyjádření religiozity. Tento fakt vyplývá z rostoucí diverzity a individualizace v oblasti náboženství. Nelze proto identifikovat něco jako jednu ,typicky (pozdně) moderní formu náboženství“. Vedle sebe mohou existovat situace popsatelné jako „believing without belonging“ (privatizovaná religiozita) a „belonging without believing“ (náboženství jako pamět'). Stejně tak lze pozorovat souběžné procesy „klasické“ sekularizace, náboženské deprivatizace a „spiritualizace“ (posun od náboženství ke spiritualitě - Heelas, Woodhead 2005). Sociologie náboženství by proto měla opustit představu o jednotné šabloně vztahu mezi náboženstvím a modernitou a všemi svými dostupnými prostředky se snažit zachytit specifické podoby náboženského života $\mathrm{v}$ konkrétních sociálních a kulturních kontextech. ${ }^{52}$ Konceptuální aparát použitelný pro empirické zkoumání k tomu již dnes k dispozici má.

\section{Literatura}

BECKFORD, James A. Religion and Advanced Industrial Society. London : Unwin Hyman, 1989. 189 s. ISBN 0-41508-462-8.

BECKFORD, James A. Postmodernity, High Modernity and New Modernity: Three Concepts in Search of Religion. In FLANAGAN, K., JUPP, P. C. (eds.) Postmodernity, Sociology and Religion. Basingstoke : Macmillan, 1996, s. 30-47. ISBN 0-31216-109-3.

BECKFORD, James A. Social Theory and Religion. Cambridge : Cambridge University Press, 2003. 262 s. ISBN 0-52177-431-4.

BELLAH, Robert N. Religious Evolution. American Sociological Review, 1964, č. 29, s. 358-374. ISSN 0003-1224.

BELLAH, Robert N. Civil Religion in America. In ALEXANDER, J. C., SEIDMAN, S. (eds.) Culture and Society. Contemporary Debates. Cambridge : Cambridge University Press, 1990, s. 262-272. ISBN 0-52135-939-2.

BERGER, Peter L. The Sacred Canopy: Elements of a Sociological Theory of Religion. Garden City : Doubleday, 1967. 240 s. ISBN 0-3850-7305-4

BERGER, Peter L. The Desecularization of the World: A Global Overview. In Berger, P. L. (ed.) The Desecularization of the World. Resurgent Religion and World Politics. Washington : Ethic and Public Policy Center, 1999, s. 1-18. ISBN 0-80284-691-2.

52 Inspirativní počin v tomto ohledu představují sborníky editované Paulem Heelasem a věnující se právě problematice vztahu mezi náboženstvím a modernitou - Heelas (1998) nebo Heelas, Woodhead (2000). 
BESECKE, Kelly S. Beyond Literalism: Reflexive Spirituality and Religious Meaning. In AMMERMAN, N. (ed.) Everyday Religion: Observing Modern Lives. New York : Oxford University Press, 2007, s. 169-186. ISBN 0-19530-541-8.

BEYER, Peter. Religion and Globalization. London : Sage, 1994. 250 s. ISBN 0-80398-917-2. BEYER, Peter. The Modern Emergence of Religions and a Global Social System for Religion. International sociology, 1998, č. 2, s. 151-172. ISSN 0268-5809.

BEYER, Peter. Secularization from the Perspective of Globalization: A Response to Dobbelaere. Sociology of Religion, 1999, č. 3, s. 289-301. ISSN 0038-0210.

BEYER, Peter. Religions in Global Society. 1. vyd. London : Routledge, 2006. 323 s. ISBN 0-41539-319-1.

BRUCE, Steve (ed.). Religion and Modernization. Sociologists and Historians Debate the Secularization Thesis. Oxford : Clarendon Press, 1992. 240 s. ISBN 0-19827-369-X.

BRUCE, Steve. The Curious Case of the Unnecessary Recantation: Berger and Secularization. In WOODHEAD, L., HEELAS, P., MARTIN, D. (eds.) Peter Berger and the Study of Religion. 1. vyd. London : Routledge, 2001, s. 87-100. ISBN 0-41521-532-3.

BRUCE, Steve. God is Dead. Secularization in the West. Oxford : Blackwell, 2002. 288 s. ISBN 0-63123-275-3.

CAMPBELL, Robert A. Theodicy, Distribution of Risk, and Reflexive Modernization: Explaining the Cultural Significance of New Religious Movements. In BECKFORD, J. A., WALLIS, J. (eds.) Theorising Religion. Classical and Contemporary Debates. Aldershot : Ashgate, 2006, s. 90-104. ISBN 0-754-64068-X.

CASANOVA, Jose. Public Religions in the Modern World. Chicago : University of Chicago Press, 1994. 330 s. ISBN 0-22609-535-5.

CASTELLS, Manuel. The Rise of the Network Society. Oxford : Blackwell, 1996. 556 s. ISBN 1-55786-617-1.

CIPRIANI, Roberto. Sociology of Religion. An Historical Introduction. New York : Aldine de Gruyter, 2000. 304 s. ISBN 0202305929

DAVIE, Grace. Europe: The Exception That Proves the Rule?. In BERGER, P. L. (ed.) The Desecularization of the World. Resurgent Religion and World Politics. Washington : Ethic and Public Policy Center, 1999, s. 65-83. ISBN 0-80284-691-2.

DAVIE, Grace. Religion in Modern Europe. A Memory Mutates. Oxford : Oxford University Press, 2000. 232 s. ISBN 0-19828-065-3.

DAVIE, Grace. The Persistence of Institutional Religion in Modern Europe. In WOODHEAD, L., HEElAS, P., MARTIN, D. (eds.) Peter Berger and the Study of Religion. 1. vyd. London : Routledge, 2001, s. 101-111. ISBN 0-41521-532-3.

DAVIE, Grace. Europe: The Exceptional Case. Parameters of Faith in the Modern World. London : Darton, Longman and Todd, 2002. 192 s. ISBN 0-23252-425-4.

DAVIE, Grace. Patterns of Religion in Western Europe: An Exceptional Case. In FENN, R. K. (ed.) The Blackwell Companion to Sociology of Religion, Oxford : Blackwell, 2003, s. 264-278. ISBN 0-63121-241-8.

DAVIE, Grace. New Approaches in the Sociology of Religion: A Western Perspective. Social Compass, 2004, č. 1, s. 73-84. ISSN 0037-7686.

DAVIE, Grace. The Sociology of Religion. London : Sage, 2007. 296 s. ISBN 0-76194-892-9. 
DAWSON, Lorne L. Privatisation, Globalisation, and Religious Innovation: Giddens' Theory of Modernity and the Refutation of Secularization Theory. In BECKFORD, J. A., WALLIS, J. (eds.) Theorising Religion. Classical and Contemporary Debates. Aldershot : Ashgate, 2006, s. 105-119. ISBN 0-75464-068-X.

DOBBELAERE, Karel. Secularization Theories and Sociological Paradigms: Convergences and Divergences. Social Compass, 1984, č. 2-3, s. 199-219. ISSN 0037-7686.

DOBBELAERE, Karel. Secularization: An Analysis at Three Levels. Brussels : P. I. E. - Peter Lang, 2002. 214 s. ISBN 9-05201-985-1.

DOBBELAERE, Karel. Religion in Modernity. In A. CROCKETT, A., O'LEARY, R. (eds.). Patterns and Precesses of Religious Change in Modern Industrial Societies. Europe and the United States. Lewiston: The Edwin Mezzlen Press, 2004, s. 139-164. ISBN 0-77346-431-X.

DURKHEIM, Emile. Elementárni formy náboženství. Praha : Oikoymenh, 2002. 504 s. ISBN 80-7298-056-4.

DURKHEIM, Emile. Společenská dělba práce. Brno : Centrum pro demokracii a kulturu, 2004. 376 s. ISBN 80-7325-041-1.

EISENSTADT, Shmuel. Multiple Modernities. Daedalus, 2000, č. 1, s. 1-29. ISSN 0011-5266.

GLASNER, Peter E. The Sociology of Secularisation. A Critique of Concept. London : Routledge \& Kegan Paul, 1977. 137 s. ISBN 0-71008-455-2.

GLOCK, Charles Y. ; STARK, Rodney. Religion and Society in Tension. Chicago : McNally, 1965. 316 s. ISBN 0-52868-706-9.

HALMAN, Loek ; PETTERSON, Thorleif. Globalization and Patterns of Religious Belief Systems. In HALMAN, L., RIIS, O. (eds.) Religion in Secularizing Society. The Europeans' Religion at the End of the 20th Century. Leiden : Brill, 2003, s. 185-204. ISBN 9-00412-622-8.

HEELAS, Paul. (ed.) 1998. Religion, Modernity and Postmodernity. Oxford: Blackwell.

HEELAS, Paul ; WOODHEAD, Linda. (eds.) Religion in Modern Times: An Anthology. London : Blackwell, 2000. 536 s. ISBN 0-63121-074-1.

HEELAS, Paul ; WOODHEAD, Linda. The Spiritual Revolution. Why Religion is Giving Way to Spirituality. Oxford : Blackwell Publishing, 2005. 224 s. ISBN 1-40511-959-4.

HEFNER, Robert W. Multiple Modernities: Christianity, Islam and Hinduism in a Globalizing Age. Annual Review of Anthropology, 1998, s. 83-104. ISSN 0084-6570.

HELLEMANS, Staf. Secularization in a Religiogeneous Modernity. In LAERMANS, R., WILSON, B. R., BILLIET, J. (eds.) Secularization and Social Integration. Papers in Honor of Karel Dobbelaere. Leuven : Leuven University Press, 1998, s. 67-81. ISBN 9-06186-932-3.

HERVIEU-LÉGER, Daniele. Religion as a Chain of Memory. Cambridge : Polity Press, 2000. 216 s. ISBN 0-81352-828-3.

INGLEHART, Ronald. The Silent Revolution: Changing Vaules and Political Styles in Advanced Industrial Society. Princeton : Princeton University Press, 1977. ISBN 0-69110-038-1.

INGLEHART, Ronald. Culture Shift in Advanced Industrial Society. Princeton : Princeton University Press, 1990. 504 s. ISBN 0-69102-296-8. 
INGLEHART, Ronald. Modernization, Postmodernization: Cultural, Economic and Political Change in 43 Societies. Princeton : Princeton University Press, 1997. 453 s. ISBN 0-69101-180-X.

INGLEHART, Ronald ; BAKER, Wayne. Modernization, Cultural Change, and the Persistence of Traditional Values. American Sociological Review 2000, č. 1, s. 19-51. ISSN 0003-1224.

INGLEHART, Ronald ; NORRIS, Pippa. Sacred and Secular. Religion and Politics Worldwide. Cambridge : Cambridge University Press, 2004. 329 s. ISBN 0-52183-984-X.

KATZENSTEIN, Peter J. Multiple Modernities as Limits to Secular Europeanization? In BYRNES, T. A., KATZENSTEIN, P. J. (eds.) Religion in an Expanding Europe. Cambridge : Cambridge University Press, 2006, s. 1-33. ISBN 0-52185-926-3.

KELLER, Jan. Teorie modernizace. Praha : Slon, 2007. 194 s. ISBN 80-8642-966-0.

LAMBERT, Yves. Religion in Modernity as a New Axial Age: Secularization or New Religious Forms? Sociology of Religion, 1999, č. 3, s. 303-333. ISSN 1069-4404.

LAMBERT, Yves. A Turning Point in Religious Evolution in Europe. Journal of Contemporary Religion, 2004, č. 1, s. 29-45. ISSN 1353-7903.

LUCKMANN, Thomas. The Invisible Religion. The Problem of Religion in Modern Society. New York : The Macmillan Company, 1967. ISBN 0-02576-700-3.

LUHMANN, Niklas. Funktion der Religion. Frankfurt : Suhrkamp, 1977. 323 s. ISBN 3-51828-007-4.

LUŽNÝ, Dušan. Náboženství a moderní společnost. Brno : Masarykova univerzita, 1999. 183 s. ISBN 80-210-2224-8.

LYON, David. Ježíš v Disneylandu. Náboženství v postmoderní době. Praha : Mladá fronta. 2002. 272 s. ISBN 80-204-0941-6.

MARTIN, David. The Religious and the Secular. Studies in Secularization. London : Routledge \& Kegan Paul, 1969. 164 s.

MARTIN, David. A General Theory of Secularization. Oxford : Blackwell, 1978. 353 s. ISBN 0-06136-179-8.

MARTIN, David. The Secularization Issue: Prospect and Retrospect. The British Journal of Sociology, 1991, č. 3, s. 465-475. ISSN 0007-1315.

MARTIN, David. On Secularization. Towards a Revised General Theory. Aldershot : Ashgate, 2005. 206 s. ISBN 0-75465-322-6.

McLEOD, Hugh. Náboženství a lidé západní Evropy (1789-1989). 1. vyd. Brno: CDK, 2007. 215 s. ISBN 978-80-7325-124-6.

McLEOD, Hugh ; USTORF, Werner (eds.) The Decline of Christendom in Western Europe, 1750-2000. Cambridge : Cambridge University Press, 2003. 244 s. ISBN 0-52181-493-6.

NEŠPOR, Zdeněk. Ekonomistický redukcionismus a humanistická perspektiva v současné sociologii náboženství. Religio, Revue pro religionistiku, 2004, č. 2, s. 163 c 186. ISSN 1210-3640.

NEŠPOR, Zdeněk ; LUŽNÝ, Dušan. Sociologie náboženství. 1. vyd. Praha : Portál, 2007. s. ISBN 978-80-7367-251-5. 
RABUŠIC, Ladislav. Tichá revoluce neboli od materialismu k postmaterialismu v západních společnostech. Sociologický časopis, 1990, s. 505-517. ISSN 0038-0288.

RÉMOND, René. Náboženství a společnost v Evropě. Praha : Lidové noviny, 2003. 273 s. ISBN 80-7106-496-3.

RIIS, Ole. The Study of Religion in Modern Society. Acta sociologica. 1993, s. 371-383. ISSN 0001-6993.

ROBERTSON, Roland. The Sacred and the World System. In HAMMOND, P. E. (ed.) The Sacred in a Secular Age. Berkeley : University of California Press, 1985, s. 347. ISBN 0-52005-343-5.

ROBERTSON, Roland. A New Perspective on Religion and Secularization in the Global Context. In HADDEN, J. K., SHUPE, A. (eds.) Secularization and Fundamentalism Reconsidered. Religion and Political Order, Vol. III. New York : Paragon House, 1989. s. 63-77. ISBN 0-91375-797-7.

ROBERTSON, Roland. Community, Society, Globality, and the Category of Religion. In BARKER, E., J. A. BECKFORD, J. A., DOBBELAERE, K. (eds.) Secularization, Rationalism and Sectarianism. Oxford : Clarendon Press, 1993. s. 1-17. ISBN 0-19827-721-0.

ROBERTSON, Roland ; CHIRICO, J. Humanity, Globalization, and Worldwide Religious Resurgence: A Theoretical Exploration. Sociological Analysis, 1985, č. 3, s. 219-242. ISSN 0161-0422.

SHINER, L. The Concept of Secularization in Empirical Research. Journal for the Scientific Study of Religion, 1967, č. 2, s. 207-220. ISSN 0021-8294.

SOMMERVILLE, C. J. Secular Society/Religious Population: Our Tacit Rules for Using the Term 'Secularization'. Journal for the Scientific Study of Religion, 1998, č. 2, s. 249-253. ISSN 0021-8294.

SPOHN, W. Multiple Modernity, Nationalism and Religion. Current Sociology, 2003, č. 3-4, s. 265-286. ISSN 0011-3921.

STARK, Rodney ; BAINBRIDGE, William S. The Future of Religion. Berkeley : University of California Press, 1985. 600 s. ISBN 0-52005-731-7.

STARK, Rodney ; BAINBRIDGE, William S. A Theory of Religion. Berkeley : University of California Press, 1987. 390 s. ISBN 0-8204-0356-3

TSCHANNEN, Olivier. The Secularization Paradigm: A Systematization. Journal for the Scientific Study of Religion, 1991, č. 4, s. 395-415. ISSN 0021-8294.

TSCHANNEN, Olivier. Sociological Controversies in Perspective. Review of Religious Research, 1994, č. 1, s. 70-86. ISSN 0034-673X.

TSCHANNEN, Olivier. Religion as a Resource for the Creation of Personal Identity in a Secularized Context. In LAERMANS, R., WILSON, B. R., BILLIET, J. (eds.) Secularization and Social Integration. Papers in Honor of Karel Dobbelaere. Leuven : Leuven University Press, 1998. s. 253-260. ISBN 9-06186-932-3.

VOYÉ, Liliane. Secularization in a Context of Advanced Modernity. Sociology of Religion, 1999, č. 3, s. 275-288. ISSN 1069-4404. 
WARNER, Stephen R. Work in Progress Towards a New Paradigm for the Sociological Study of Religion in the United States. American Journal of Sociology, 1993, č. 5, s. 1044-1093. ISSN 0002-9602.

WILLAIME, Jean P. Religion, Individualization of Meaning, and the Social Bond. In LAERMANS, R., WILSON, B. R., BILliET, J. (eds.) Secularization and Social Integration. Papers in Honor of Karel Dobbelaere. Leuven : Leuven University Press, 1998, s. 261-275. ISBN 80-7106-496-3.

WILLAIME, Jean P. Religion in Ultramodernity. In BECKFORD, J. A., WALLIS, J. (eds.) Theorising Religion. Classical and Contemporary Debates. Aldershot : Ashgate, 2006, s. 77-89. ISBN 0-75464-068-X.

WILSON, Bryan R. Religion in Secular Society. Baltimore : Penguin Books, 1969. s. 288. ISBN 0-14021-012-1.

YOUNG, Lawrence A. (ed.) Rational Choice Theory and Religion. Summary and Assessment. 1. vyd. New York: Routledge, 1997. 256 s. ISBN 0-41591-192-3.

\section{Autor}

Roman Vido působí jako odborný asistent na katedře sociologie Fakulty sociálních studií Masarykovy univerzity v Brně. Mezi jeho pole zájmu patří sociologie náboženství, obecná sociologie a klasické sociologické teorie, kterým se věnuje pedagogicky i badatelsky. Kontakt:vido@fss.muni.cz 